\title{
Sodium potassium adenosine triphosphatase activity in preterm and term infants and its possible role in sodium homeostasis during maturation
}

T Bistritzer, M Berkovitch, M J Rappoport, S Evans, S Arieli, M Goldberg, I Tavori, M Aladjem

\begin{abstract}
Aim-To investigate sodium $\left(\mathbf{N A}^{+}\right)$potassium $\left(\mathrm{K}^{+}\right)$adenosine triphosphatase (ATPase) activity in newborn infants at different gestational ages, to elucidate the mechanism underlying poor renal sodium conservation in preterm infants.

Methods-Fifty three healthy newborn infants, gestational age 30-42 weeks, were studied. Umbilical cord red blood cell $\mathrm{Na}^{+} \mathrm{K}^{+}$ATPase activity, plasma renin activity, and plasma aldosterone activities were measured in all of them. Red blood cell $\mathrm{Na}^{+} \mathrm{K}^{+}$ATPase activity was reexamined in eight preterm infants, one and two weeks after birth. Total and ouabain sensitive ATPase activity was measured spectrophotometrically using a method that couples ATP hydrolysis with NADH oxidation.
\end{abstract}

Results-Red blood cell $\mathrm{Na}^{+} \mathrm{K}^{+}$ATPase activity was significantly lower $(p<0.01)$ in preterm babies with a gestational age below 35 weeks, compared with those with aged 35 weeks and above: $2.3(0.8)$ and 6.7 (1.3) $\mathbf{n m o l} \mathrm{NADH} / \mathrm{minute} / \mathrm{mg}$ protein, respectively. There was no correlation between gestational age, $\mathrm{Na}^{+} \mathrm{K}^{+}$ATPase, plasma renin activity and aldosterone values either in the preterm or term babies. Two weeks after birth, irrespective of gestational age, the enzyme activity of the preterm babies increased to values similar to those observed in the term neonates at birth.

Conclusion-The differences in sodium homeostasis between term and preterm babies are modulated via changes in $\mathrm{Na}^{+} \mathrm{K}^{+}$ATPase activity.

(Arch Dis Child Fetal Neonatal Ed 1999;81:F184-F187)

Internal Medicin

M J Rappoport

Department of Biochemical Pathology $S$ Evans

Department of Obstetrics

S Arieli

Department of Neonatology

M Goldberg

I Tavori

Correspondence to:

Dr Tzvy Bistritzer.

Email:

mberkovitch@asaf.health.gov.il

Accepted 25 May 1999

Regulation of sodium balance has an essential role in postnatal growth and maturation. Significant differences in sodium handling between prematurely born and term babies have been observed. The term baby is characterised by a positive sodium balance and a limited ability to excrete a sodium load. ${ }^{1-3}$ In contrast, the premature infant, when fed with conventional "humanised" formula ${ }^{4-8}$ or during intravenous maintenance therapy, ${ }^{9}$ is prone to develop an increasingly negative sodium bal- ance due to a reduced capacity for renal sodium conservation.

The long term consequences of a sodium deficient state are unknown, but its occurrence during the postnatal period of rapid brain growth is worrying and certainly in contrast to the rapid intra-uterine accretion of sodium (and other elements) into the brain. The offspring of rats fed a sodium deficient diet during pregnancy had a decreased brain weight and reduced brain protein and RNA content, compared with normal controls. ${ }^{10}$ Furthermore, in young mice hyponatraemia persisting for several days or more is associated with a significant loss of brain sodium ${ }^{11}$ and potassium $^{12}$ and possibly amino acid ${ }^{13}$ content.

Several mechanisms to explain the inappropriate natriuresis in preterm infants have been suggested: (i) low proximal tubular reabsorptive capacity due to a functional immaturity of the glomerulotubular balance, ${ }^{14}$ possibly related to a failure of a tubuloglomerular feedback via the macular densa ${ }^{5}$; (ii) unresponsiveness of the renal tubule in the premature infant to aldosterone $\mathrm{e}^{15}$; (iii) low activity of the transporting enzyme system $\left(\mathrm{Na}^{+} \mathrm{K}^{+}\right.$ATPase). Schmdit and Horster ${ }^{16}$ have shown low enzyme activity in all segments of the newborn rabbit tubule. $\mathrm{Na}^{+} \mathrm{K}^{+}$ATPase is expressed in almost all eukaryotic cells. It couples the hydrolysis of ATP to the vectorial transport of NA+ and $\mathrm{K}+$ across the cell membrane. The cation gradients by $\mathrm{Na}^{+} \mathrm{K}^{+}$ATPase are of fundamental importance for such vital functions as control of cell volume nutrient uptake, membrane excitability, and transepithelial transport of sodium. ${ }^{17}$

That being so, we set out to investigate red blood cell $\mathrm{Na}^{+} \mathrm{K}^{+}$ATPase activity in neonates at various gestational ages on the supposition that low such activity may be aetiological in the natruiresis of the premature infant.

\section{Methods}

Fifty three healthy neonates, comprising 27 preterm and 26 full term babies, were studied. Their gestational ages ranged from 30 to 42 weeks. Gestational age was estimated from the mother's menstrual history and on physical assessment of the infant, using the criteria of Dubowitz et al. ${ }^{18}$ Pregnancies were uncomplicated for diabetes, hypertension, eclampsia or other chronic diseases. Umbilical cord red blood cell $\mathrm{Na}^{+} \mathrm{K}^{+}$ATPase was assessed in all, and re-examined in eight premature infants at 
one and two weeks after birth. All the re-studied infants were in good health and none underwent an exchange transfusion.

The investigation was approved by the ethical committee of the hospital and informed consent was obtained from the parents.

Mixed umbilical cord blood was collected at birth in EDTA tubes, placed on ice, and transferred immediately to the laboratory for evaluation of red blood cell $\mathrm{Na}^{+} \mathrm{K}^{+}$ATPase activity. The method for estimating this has been described before. ${ }^{19}$ Preparation of red blood cell ghosts ${ }^{20}$ was performed on blood collected on Na-EDTA and centrifuged at $600 \times g$ for 30 minutes $\left(4^{\circ} \mathrm{C}\right)$. Packed red blood cells were washed three times in $0.9 \% \mathrm{NaCl}$ with a 5 minute centrifugation after each wash. Red blood cells were haemolysed in $10 \mathrm{mM}$ (Tris/1 mM EDTA, and ghosts were sedimented at 27 $000 \times g$ for 20 minutes $\left(4^{\circ} \mathrm{C}\right)$. The pellet was washed two to four times in $10 \mathrm{mM}$ Tris $(\mathrm{pH}$ 7.4) with a 10 minute centrifugation at 27000 $\times g\left(4^{\circ} \mathrm{C}\right)$ after each wash. Membranes were re-suspended in $20 \mathrm{mM} \mathrm{N}$-2-hydroxyethylpiperazine-N-2-ethanesulfonic acid ( $\mathrm{pH} 7.4) / 2$ mM DTT.

Total and ouabain sensitive ATPase activities were measured spectrophotometrically at $37^{\circ} \mathrm{C}$ in a thermostated Gilford 2600 spectrophotometer (Guilford Instruments Lab. Inc., Oberlin, OH, USA) using a method that couples ATP hydrolysis with NADH oxidation. ${ }^{21} \mathrm{Na}^{+} \mathrm{K}^{+}$ATPase activity was calculated by subtracting ouabain sensitive ATPase activity from total ATPase activity. The final composition of the reaction mixture was as follows: $50 \mathrm{mM}$ Tris HCI (pH 7.4); $130 \mathrm{mM} \mathrm{Na}$ $\mathrm{Cl} ; 5 \mathrm{mM} \mathrm{KCI} ; 3 \mathrm{mM} \mathrm{MgCl} ; 3 \mathrm{mM}$ vanadium free Tris-ATP; $1.5 \mathrm{mM} \mathrm{NADH} ; 0.83 \mathrm{mM}$ phosphoenolpyruvate; $1 \mathrm{IU} / \mathrm{ml}$ pyruvate kinase; and $1 \mathrm{IU} / \mathrm{ml}$ lactate dehydrogenase. Ouabain concentration, when present, was $1 \mathrm{mM}$. The reaction was started by the addition of 50 to $75 \mu \mathrm{g}$ membrane protein and run in triplicate. Results were expressed as nanomoles of NADH oxidised/minute/ mg protein. Analysis of variance for precision within and between assays yielded $\mathrm{p}$ values for the $\mathrm{F}$ ratios of $>0.5$. The lower limit of detectability was $0.2 \mathrm{nmol}$ $\mathrm{NADH} / \mathrm{min} / \mathrm{mg}$ protein. The amount of membrane proteins was measured by a modification of the method of Lowry et $a l^{22}$ with a commercial kit (Sigma Chemical Co, St Louis, MO; procedure P5656).

Plasma renin activity and aldosterone were determined by radioimmunoassay commercial kits: PRA (New England Nuclear, Boston, MA) Aldosterone (Diagnostic Products Co, Los Angeles, CA).

Results of red blood cell $\mathrm{Na}^{+} \mathrm{K}^{+}$ATPase activity are presented as the mean (SD). Significance was assessed by $t$ test for unpaired series. $P$ values of $<0.05$ were considered significant. The relation between red blood cell $\mathrm{Na}^{+} \mathrm{K}^{+}$ATPase activity and plasma renin and aldosterone values, respectively, was assessed by linear regression analysis.

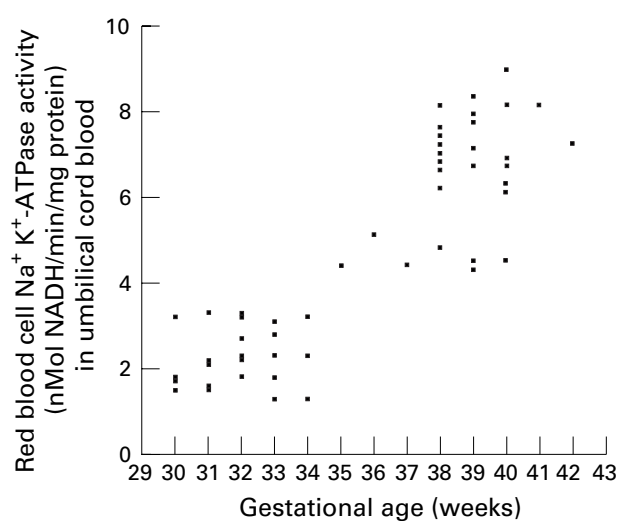

Figure 1 Relation between umbilical cord red blood cell $\mathrm{Na}^{+} \mathrm{K}^{+}$ATPase activity and gestational age.

\section{Results}

$\mathrm{Na}^{+} \mathrm{K}^{+}$ATPase activity values were significantly lower $(\mathrm{p}<0.01)$ in preterm neonates with a gestational age below 35 weeks, compared with those with a gestational age of 35 weeks and above: $2.3(0.8)$ and 6.7 (1.3) (nMol $\mathrm{NADH} / \mathrm{min} / \mathrm{mg}$ protein), respectively (fig 1). There was no correlation between gestational age and $\mathrm{Na}^{+} \mathrm{K}^{+}$ATPase activity values either in the preterm or in the more mature infants (fig $1)$.

In eight preterm neonates enzyme activity was re-examined a week and two weeks after birth (fig 2). Red blood cell $\mathrm{Na}^{+}, \mathrm{K}^{+}$ATPase activity was low in six out of these preterm infants one week after birth. However, two weeks after birth, the enzyme activity increased to values similar to those observed in term neonates in seven of them, although four could still be considered premature, based on gestational age (fig 2). These eight preterm babies had normal plasma sodium concentrations during their first two weeks of life.

No gestational age related change in plasma renin activity or aldosterone values were observed for the group as a whole or when values in neonates of less or more than 35 weeks of gestation were evaluated separately. Plasma renin activity mean values in the preterm neonates were $59.5(64.9) \mathrm{ng} / \mathrm{l} / \mathrm{s}$ and

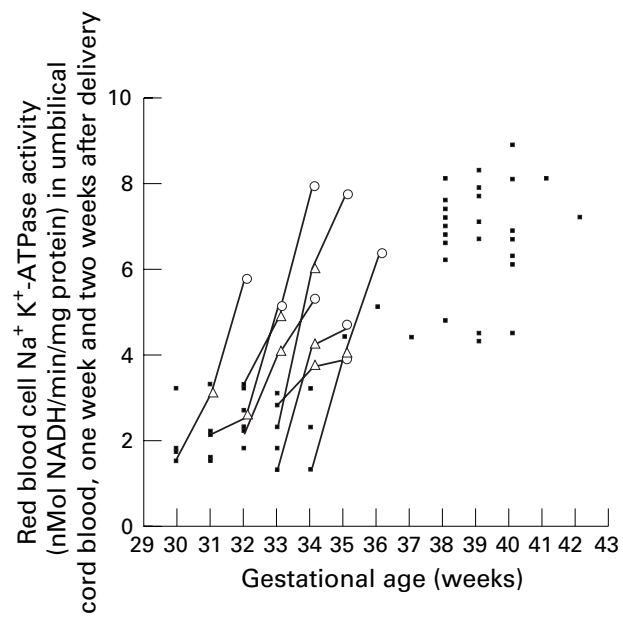

Figure 2 Umbilical cord red blood cell $\mathrm{Na}^{+} \mathrm{K}^{+}$ATPase activity (squares), re-measured one week (triangles) and two weeks (circles) after delivery. 
$35.4(41.7) \mathrm{ng} / \mathrm{l} / \mathrm{s}$ in the full term neonates; mean aldosterone concentration was 3200 (1735) pmol/1 and 2103 (1457) pmol/1, respectively. No correlation was found between red blood cell $\mathrm{Na}^{+} \mathrm{K}^{+}$ATPase activity and either plasma renin activity or aldosterone values.

\section{Discussion}

Sodium deficiency during the neonatal period, particularly in premature infants, may irreversibly affect somatic growth and the development of the nervous system. ${ }^{23}$ The term baby thrives on a rather low intake of sodium, as prevails during the period of breast feeding. ${ }^{24}$ In contrast, the premature infant, when fed conventional "humanised" infant formula, will frequently fail to thrive and become hyponatraemic, ${ }^{423} 25$ thus necessitating supplementation with a relatively high salt diet. ${ }^{26}{ }^{27}$ The negative sodium balance in the premature infant is attributed to low renal sodium conservation. ${ }^{4-9}$ A change in sodium homeostasis from a negative to a positive balance occurs at a gestational age of 33-35 weeks. ${ }^{7}$ In our study we observed constantly low red blood cell $\mathrm{Na}^{+} \mathrm{K}^{+}$ATPase activity in preterm infants which increased at 34-35 weeks of gestational age. The increase observed suggested that there may be a relatively sudden maturation of $\mathrm{Na}^{+} \mathrm{K}^{+}$ATPase activity. Our data correspond to previous observations of a change in sodium homeostasis occurring at this gestational age. ${ }^{7}$ It seems that excessive renal sodium loss in premature infants reflects the low activity of this enzymatic system. Experimental studies in rabbits have shown that $\mathrm{Na}^{+} \mathrm{K}^{+}$ATPase activity is low in all tubular segments in the neonatal period. ${ }^{16}$ Similarly, in guinea pigs the fractional reabsorption of sodium is low during fetal life and increases rapidly at term..$^{28}$ Week 34 to 36 of gestation seems to be a period of rapid maturation of various renal tubular transport mechanisms. The fractional reabsorption of $\beta_{2}$ microglobulin, ${ }^{29}$ as well as of glucose and amino acids, ${ }^{30}$ increase to adult levels during this period. The stepwise increase in renal functional development that occurs from the 34th to 36th gestational week has often been attributed to the completion of nephrogenesis that takes place during the same period. ${ }^{31}{ }^{32}$ It seems that the increase in $\mathrm{Na}^{+} \mathrm{K}^{+}$ATPase activity occurring at a gestational age of 34-35 weeks reflects a maturational process which prepares the fetus for extrauterine nutrition during which sodium supply drops precipitously, compared with its abundance in the maternal circulation during the fetal period.

We have already observed ${ }^{19}$ low red blood cell $\mathrm{Na}^{+} \mathrm{K}^{+}$ATPase activity in patients with pseudohypoaldosteronism (PHA). The increase in red blood cell enzyme values correlated with gradual clinical improvement, reduction in salt intake, and normalisation of plasma renin activity. Furthermore, Cugini et $a l^{33}$ found low $\mathrm{Na}^{+} \mathrm{K}^{+}$ATPase activity and reduced $\mathrm{Na}^{+} \mathrm{K}^{+}$transmembrane flux in the red blood cells of a child with PHA. It is therefore tempting to assume that the increase in red blood cell $\mathrm{Na}^{+} \mathrm{K}^{+}$ATPase activity in term babies occurs in the renal tubules as well.
It has been shown that in preterm infants, irrespective of gestational age, sodium balance changes from negative to positive during the second week of extrauterine life. ${ }^{7}$ We did not study sodium balance in our infants, but we showed a rise in $\mathrm{Na}^{+} \mathrm{K}^{+}$ATPase activity in preterm babies, irrespective of their gestational age, 1-2 weeks after birth. These changes were similar to those values observed in term infants at birth. The negative sodium balance seems to be counterbalanced by the high sodium content in the breast milk of mothers delivering preterm infants. ${ }^{34} 35$

Recently, it was reported that the impairment of $\mathrm{Na}+$ reabsorption across the respiratory epithelia of very premature infants may contribute to the pathogenesis of respiratory distress syndrome. ${ }^{36} \mathrm{~A}$ partial normalisation of potential difference (PD) measurement was evident within the first 72 hours of life and after 7 days the PD values were in the range reported for healthy term infants. ${ }^{36}$ These findings correspond well with the increase in $\mathrm{Na}^{+} \mathrm{K}^{+}$ATPase activity we found in the preterm infants 1-2 weeks after birth.

We did not observe any significant changes in plasma renin activity or plasma aldosterone concentrations with maturation. Similar results were also observed by others. ${ }^{15} 37{ }^{38}$ In addition, no correlation was found between plasma aldosterone values and $\mathrm{Na}^{+} \mathrm{K}^{+}$ATPase activity in preterm and term babies. The excessive renal sodium loss in preterm babies may reflect an unresponsiveness of the renal tubule to aldosterone, which rises progressively with maturation. ${ }^{715}$ A reduction in urinary potassium:sodium ratio in salt supplemented preterm babies, as previously observed, ${ }^{26}$ suggests a responsiveness of the distal tubule to mineralocorticoids. Therefore, it seems unlikely that aldosterone deficiency or lack of renal tubular response to this hormone has a significant role in the excessive renal sodium loss in preterm infants.

The results of this study indicate that the differences in sodium homeostasis between preterm and term infants may be modulated via changes in $\mathrm{Na}^{+} \mathrm{K}^{+}$ATPase activity.

We are grateful to Anji Agajany, Jane Geva and Meytal Avgil for their technical assistance.

1 Aperia A, Broberger O, Thodenius K, Zetterstrom R. Renal response to an oral sodium load in newborn full-term infants. Acta Pediatr Scand 1972;61:670-6.

2 Goldsmith DI, Drukker A, Blaufox MD, Edelmann CM Jr, Spitzer A. Hemodynamic and excretory responses of the neonatal kidney to acute volume expansion. Am $\mathcal{F}$ Physiol 1979;237:F392-F7.

3 Aladjem M, Spitzer A, Goldsmith DI. The relationship between intravascular volume expansion and natriuresis in developing puppies. Pediatr Res 1982;16:840-5.

4 Thodenius K. Renal control of sodium homeostasis in infancy. Acta Paediatr Scand (Suppl) 1974;253:1-28.

5 Aperia A, Broberger O, Elinder G, Herin P, Zetterstrom R. Postnatal development of renal function in preterm and full term infants. Acta Paediatr Scand 1981;70:183-7.

6 Sulyok E. The relationship between electrolyte and acid base balance in the premature during early postnatal life. Biol Neonate 1971;17:227-37.

7 Al-Dahhan J, Haycock GB, Chantler C, Stimmler L. Sodium homeostasis in term and preterm neonates. I Renal aspects. Arch Dis Child 1983;58:335-42.

8 Engelke CS, Shah LB, Vasan U, Raye RJ. Sodium balance in very low birth weight infants. F Pediatr 1978;93:837-41.

9 Aperia A, Broberger O, Thodenius K, Zetterstrom R. Renal control of sodium and water balance in newborn infants during intravenous maintenance therapy. Acta Paediatr during intravenous maint
Scand $1975 ; 64: 725-31$. 
10 Bursey RG, Watson ML. The effect of sodium restriction during gestation on offspring brain development in rats. during gestation on offspring b

11 Rymer MM, Fishman RA. Protective adaptation of brain to water intoxication. Arch Neurol 1973;28:49-54.

12 Dila CJ, Pappius HM. Cerebral water and electrolytes: an experimental model of inappropriate secretion of antidiuretic hormone. Arch Neurol 1972;26:85-90.

13 Thurston JH, Hauhart RE, Jones EM, Ater JL. Effects of salt and water loading on carbohydrate and energy metabolism and levels of selected aminoacids in the brains of young mice. F Neurochem 1975;24:953-7.

14 Siegel SR, Oh W. Renal function as a marker of human fetal maturation. Acta Paediatr Scand 1976;65:481-5.

15 Aperia A, Broberger O, Herin P, Zetterstrom R. Sodium excretion in relation to sodium intake and aldosterone excretion in newborn preterm and full term infants. Acta Paediatr Scand 1979;68:813-17.

16 Schmidt U, Horster M. Na-K activated ATPase: activity maturation in rabbit nephron segments dissected in vitro. Am 7 Physiol 1977;233:F55-F60.

17 Jorgensen P. Structure, function and regulation of $\mathrm{Na}^{+}, \mathrm{K}^{+}-$ ATPase in the kidney. Kidney Int 1986;29:10-20.

18 Dubowitz LMS, Dubowitz V, Goldberg C. Clinical assessment of gestational age in the newborn infant. $\mathscr{f}$ Pediatr 1970;77:1-10.

19 Bistritzer T, Evans S, Cotariu D, Goldberg M, Aladjem M. Reduced $\mathrm{Na}^{+}, \mathrm{K}^{+}$-ATPase activity in patients with pseudohypoaldosteronism. Pediatr Res 1994;35:372-5.

20 Dodge JT, Mitchell C, Hanahan DJ. The preparation and chemical characteristics of hemoglobin-free ghosts of human erythrocytes. Arch Biochem 1963;100:119-30.

21 Schoner W, Von Ilberg C, Kramer R, Shubert W. On the mechanism of $\mathrm{Na}^{+}$and $\mathrm{K}^{+}$-stimulated hydrolysis of adenosine triphosphate purification and properties of a $\mathrm{Na}^{+}$and $\mathrm{K}^{+}$-activated ATPase from ox brain. Eur $\mathcal{f}$ Biochem 1967;1:334-43.

22 Peterson GL. A simplification of the protein assay method of Lowry et al. which is more generally applicable. Anal of Lowry et al. which is

23 Roy RN, Chance GW, Radde JC, Hill DE, Willis DM, Sheepers J. Late hyponatremia in very low birth weight infants (<1.3 kilograms). Pediatr Res 1976;10:526-31.

24 Spitzer A. The role of the kidney in sodium homeostasis during maturation. Kidney Int 1982;21:539-45.
25 Day GM, Raddle IC, Balfe JW, Chance GW. Electrolyte ab GM, Raddle IC, Balfe JW, Chance GW. Electrolyte abnormalities in

26 Al-Dahhan J, Haycock GB, Nichol B, Chantler C, Stimmler L. Sodium homeostasis in term and preterm neonates. III Effect of salt supplementation. Arch Dis Child 1984;59:945-50.

27 Aviv A, Kobayashi T, Higashino H. Bauman JW Jr, Yu SS. Chronic sodium deficit in the immature rat: its effect on adaptation to sodium excess. Am F Physiol1 982;242:E241E7. 28 Merlet-Benichou C, De Rouffignac D. Renal clearance
studies in fetal and young guinea pigs: effect of salt loading. Am F Physiol 1977;232:178-88.

29 Aperia A, Broberger O. Beta-2-microglobulin, an indication of renal tubular maturation and dysfunction in the newborn. Acta Paediatr Scand 1979;68:669-76.

30 Arant BS. Developmental patterns of renal functional maturation compared in the human neonate. If Pediatr ration compar

31 MacDonald MS, Emery JL. The late intrauterine and postnatal development of human renal glomeruli. I Anat natal development

32 Potter EL, Thierstein ST. Glomerular development in the kidney as an index of fetal maturity. $\mathcal{F}$ Pediatr. 1943;22:695-706.

33 Cugini P, Notoli G, Gerlini G, et al. Enythrocyte transmembrane $\mathrm{Na}$ and $\mathrm{K}$ fluxes in pseudohypoaldosteronism. Biochem Med Metab Biol 1992;48:241-54.

34 Schanler RJ, Oh W. Composition of breast milk obtained from mothers of premature infants as compared to breast milk obtained from donors. $\mathcal{F}$ Pediatr 1980;96:679-81.

35 Aperia A, Broberger O, Hein P, Zetterstrom R. Salt content in human breast milk during the first three weeks after delivery. Acta Paediatr Scand 1979;68:441-2

36 Barker PM, Gaven CW, Lawson EE, Knowles MR. Decreased sodium ion absorption across nasal epithelium of very premature infants with respiratory distress syndrome. F Pediatr 1997;130:373-7.

37 Honour JW, Valman HB, Shackleton CHL. Aldosterone and sodium homeostasis in preterm infants. Acta Paediatr sodium homeostasis

38 Dillon MJ, Gillin MEA, Ryners JM, de Swiet M. Plasma renin activity and aldosterone concentration in the human newborn. Arch Dis Child 1976;51:537-40. 